\title{
Effect of fungal incidence on physiological quality of tobacco seeds used in Brazil
}

\section{Efeito da incidência de fungos na qualidade fisiológica de sementes de tabaco utilizadas no Brasil}

\author{
Mariane Sayuri Ishizuka1*, Maria Heloisa Duarte de Moraes', Maria Helena Carmignani Pescarin Chamma', \\ Carlos Eduardo Pulcinelli', José Otavio Machado Menten'
}

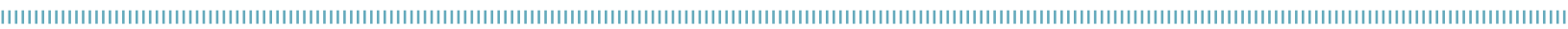

\begin{abstract}
The objectives of the present project were to evaluate the sanity and germination of tobacco seed samples cultivated in Brazil and to identify potential pathogenic fungi to the culture. Thirty-four representatives samples of tobacco seeds were evaluated through germination and sanity test by the blotter-test. On the germination test, results were expressed in percentage of seedlings considered normal, abnormal and non-germinated seeds. The percentage of seeds germination varied between 54.5 and $90 \%$. According to sanity test, it was verified the incidence of Alternaria alternata, Cladosporium spp., Fusarium spp., and Phoma spp. The incidence of A. alternata varied from 3 to $67 \%$, and Fusarium spp. varied from 0 to $19 \%$. There was significative positive correlation between the incidence of $A$. alternata and the percentage of seed germination. Species of Alternaria and Fusarium can be potential pathogens to tobacco culture and an alarm for the necessity of seed treatment of the seeds that are transporting these fungi.
\end{abstract}

KEYWORDS: germination; symptoms; Alternaria alternata; Fusarium spp.
RESUMO: Os objetivos do presente trabalho foram avaliar a sanidade e a germinação de amostras de sementes de tabaco utilizadas no Brasil e identificar fungos potencialmente fitopatogênicos à cultura. Foram avaliadas 34 amostras representativas de lotes de sementes de tabaco, por meio dos testes de germinaçáo, do método do rolo de germinação, e sua sanidade pelo método do papel de filtro. Os resultados do teste de germinação foram expressos em porcentual de plântulas consideradas normais, anormais e sementes não germinadas. A porcentagem de germinação das sementes variou entre 54,5 e 90\%. Mediante o teste de sanidade, foi verificada a incidência dos fungos Alternaria alternata, Cladosporium spp., Fusarium spp. e Phoma spp. A incidência de A. alternata variou de 3 a $67 \%$, e Fusarium spp., de 0 a $19 \%$. Houve correlação significativa positiva entre a incidência de $A$. alternata e a porcentagem de germinação das sementes. Espécies dos gêneros Alternaria e Fusarium podem ser potenciais patógenos para a cultura do tabaco, alertando para a necessidade do tratamento das sementes portadoras desses fungos.

PALAVRAS-CHAVE: germinação; sintomas; Alternaria alternata; Fusarium spp. 
The species Nicotiana tabacum L., known as tobacco, is an herbaceous perennial plant in the family Solanaceae. In Brazil, tobacco growing has a significant socioeconomic importance mainly in the southern region, where Rio Grande do Sul, Santa Catarina and Paraná states are responsible for $97 \%$ of national production. In the 2013/2014 crop, production of tobacco leaves in Brazil amounted roughly 751,000 tons, distributed among 651 municipalities (SINDITABACO, 2015).

The presence of fungi in a seed sample affects its sanity quality, in addition to hindering assessments of its physiological potential, often expressed by the reduction in the germination percentage under laboratory conditions (FERRAZ; CALVI, 2010). The sanitary test is also an essential tool to stop seeds from acting as primary inoculum, preventing the introduction of new pathogens in indene areas, and clarifying the causes of low germination (BRASIL, 2009a).

Several diseases compromise the development of tobacco crops in all stages, from sowing to adult plants. Many pathogens can be associated to seeds, causing damages such as death at pre-emergence, root rot, seedling damping-off, necrotic spots in leaves, stems, fruit, deformities like hypertrophy and underdevelopment, tissue discoloration and latent infections (NEERGAARD, 1979).

Thus, a contaminated or infected seed is one of the most efficient means of introducing and accumulating pathogens inoculum in farming areas (NEERGAARD, 1979; MACHADO, 1988), in addition to being an efficient mean for pathogen survival (KIMATI, 1980).

The international literature reports on five fungal species in the tobacco seed: Alternaria alternata, Alternaria longipes, Botrytis cinerea, Cercospora nicotianae and Colletotrichum tabacum (RICHARDSON, 1990).

However, there is few information for the tobacco culture about fungi transmitted by seeds in Brazil and in the world, as well as on effects of these fungi on seed quality. Similarly, to other agricultural crops, it is necessary to ensure whether this type of association is related to diseases that occur in the field, which makes the seed sanity assessment an essential tool to establish measures for disease control.

In view of the importance of fungi associated with seeds, this study aimed to assess sanity and germination of tobacco seeds used in Brazil and identify potential pathogenic fungi in the seeds.

The analyses were performed in the Seed Pathology Laboratory inserted into the Department of Plant Pathology and Nematology and in the Seed Production Laboratory into the Department of Crop Science, located at Escola Superior de Agricultura "Luiz de Queiroz" at Universidade de São Paulo (ESALQ-USP). From July to December 2013, we assessed 34 representative seed samples from lots, provided by the enterprise Souza Cruz S/A -25 seeds lots belonged to the Virginia Group and nine to the Burley Group, produced in the 2012/2013 crop in the municipalities of Mafra (Santa Catarina, Brazil), Nova Esperança (Paraná, Brazil) and Rio Negro (Paraná, Brazil).

The sanity test was carried out through the blotter-test method, using four replications of 50 seeds, wrapped individually in plastic Petri dishes, on three blotter-test discs moistened with distilled water, spaced $1-2 \mathrm{~cm}$ from each other. Later, the seeds were kept in an incubation chamber, at $20^{\circ} \mathrm{C} \pm 2^{\circ} \mathrm{C}$, alternating $12 \mathrm{~h}$ under white fluorescent light and $12 \mathrm{~h}$ in the dark, for a period of seven days, according to the Analysis Manual of Seed Sanity (BRASIL, 2009b). To detect fungi, the seeds were examined individually under a stereomicroscope, resolution 30-80X. Whenever necessary, the pathogen identity was confirmed through slides observation under the optical microscope, with the aid of the literature available. The results were expressed as percentage of occurrence of the fungi identified.

The germination test was performed in Gearbox type, using four repetitions of 50 seeds arranged individually. The boxes containing the seeds were placed in a germinator at $20-30^{\circ} \mathrm{C}$, with alternation of light for 16 hours. Germination results were expressed as percentage of normal seedlings assessed seven days after the test, obtaining the first germination count, and the final count 16 days after incubation (BRASIL, 2009a). The results were expressed as percentage of normal seedlings, abnormal seedlings and non-germinated seeds. The seedlings evaluated as normal showed entire issuing of roots and shoot. Abnormal seedlings that showed absence of pathogens were considered as deformed. Non-germinated seeds were those that did not issue any structure due to internal conditions of the seed and/or fungal infection. During the germination assessment, we identified and quantified the incidences of fungi in abnormal seedlings and non-germinated seeds. Seedlings with infection symptoms and no fungal growth were placed in plastic Petri dishes containing two sheets of filter paper moistened with distilled water and taken to an incubation chamber for 2-4 days to check for fungal growth and confirm the pathogen presence.

In order to confirm the identification of the fungi detected in the sanity and germination tests, mycelial isolation was performed collecting structures of the fungi grown on the seeds or seedlings, and placing them in a potato-dextrose-agar (PDA) culture medium. For fungi identification, the literature concerning their taxonomy was consulted (RICHARDSON, 1990; BARNETT; HUNTER, 1998).

The experimental design was completely randomized, and the data were subjected to the analysis of variance (ANOVA). The means were compared by the Scott-Knott test $(\mathrm{p}<0.05)$. All analyses were performed using the statistical program Assistat 7.7 beta version (SILVA; AZEVEDO, 2002). We also performed analyses of simple linear correlation between the 
incidences of fungi observed in the sanity test with the percentages of first count, total germination, abnormal seedlings and dead seeds.

The results of the sanity test showed high incidence of fungi in seeds, with predominance of $A$. alternata, Cladosporium spp. and Fusarium spp. with significant variations for their incidences between samples of the same cultivar (Table 1). SEGATO; GABALDI (2012) also reported the association of these fungi to tobacco seeds, although with lower incidences, in samples freshly harvested in the municipality of Ituverava, São Paulo State.

Table 1. Incidence (\%) of fungi in tobacco seed batches from the 2012/2013 crop, produced by the enterprise Souza Cruz S/A.

\begin{tabular}{|c|c|c|c|c|}
\hline Cultivar & Lot & $\begin{array}{c}\text { Alternaria } \\
\text { alternata }\end{array}$ & $\begin{array}{c}\text { Fusarium } \\
\text { spp. }\end{array}$ & $\begin{array}{c}\text { Cladosporium } \\
\text { spp. }\end{array}$ \\
\hline \multirow{2}{*}{$\csc 439^{1}$} & 160 & $67 a$ * & $6 c$ & $17 \mathrm{a}$ \\
\hline & 67 & $35 c$ & $15 a$ & $10 \mathrm{~b}$ \\
\hline \multirow{2}{*}{$\operatorname{Csc} 463^{1}$} & 178 & $66 a$ & $2 d$ & $11 b$ \\
\hline & 99 & $17 \mathrm{~d}$ & $1 \mathrm{~d}$ & $4 c$ \\
\hline \multirow{2}{*}{$\operatorname{Csc} 447^{1}$} & 166 & $48 \mathrm{~b}$ & $2 d$ & $15 a$ \\
\hline & 55 & $23 d$ & $11 \mathrm{~b}$ & $4 c$ \\
\hline \multirow{2}{*}{$\operatorname{CsC} 416^{\prime}$} & 63 & $43 \mathrm{~b}$ & $6 c$ & $18 a$ \\
\hline & 47 & $34 c$ & $19 a$ & $13 b$ \\
\hline \multirow{2}{*}{$\operatorname{Csc} 467^{1}$} & 127 & $37 c$ & $3 d$ & $11 b$ \\
\hline & 124 & $22 d$ & $6 \mathrm{c}$ & $6 c$ \\
\hline \multirow{2}{*}{$\csc 404^{1}$} & 179 & $37 c$ & $3 d$ & $12 b$ \\
\hline & 100 & $31 \mathrm{c}$ & $8 b$ & $7 c$ \\
\hline \multirow{2}{*}{$\operatorname{CSC} 454^{1}$} & 177 & $36 c$ & $2 d$ & $11 b$ \\
\hline & 103 & $30 c$ & $5 c$ & $8 c$ \\
\hline \multirow{2}{*}{$\operatorname{CSC} 4704^{\prime}$} & 107 & $36 c$ & $13 b$ & $5 c$ \\
\hline & 28 & $25 d$ & $5 c$ & $6 c$ \\
\hline \multirow{2}{*}{$\operatorname{CSC} 497^{1}$} & 92 & $36 c$ & $2 \mathrm{~d}$ & $7 c$ \\
\hline & 89 & $27 d$ & $1 d$ & $2 c$ \\
\hline \multirow{2}{*}{$\csc 444^{1}$} & 115 & $31 \mathrm{c}$ & $11 b$ & $11 b$ \\
\hline & 50 & $21 d$ & $12 b$ & $16 a$ \\
\hline \multirow{2}{*}{$\operatorname{Csc} 401^{1}$} & 45 & $30 \mathrm{c}$ & $16 a$ & $18 a$ \\
\hline & 44 & $28 d$ & $7 c$ & $12 \mathrm{~b}$ \\
\hline \multirow{2}{*}{$\operatorname{Csc} 4703^{1}$} & 34 & $30 \mathrm{c}$ & $9 \mathrm{~b}$ & $4 c$ \\
\hline & 97 & $24 d$ & $1 d$ & $7 c$ \\
\hline $\csc 405^{1}$ & 120 & $25 d$ & $5 c$ & $5 c$ \\
\hline BAT $2301^{2}$ & 163 & $24 d$ & $1 d$ & $14 b$ \\
\hline \multirow{2}{*}{$\csc 2305^{2}$} & 167 & $24 d$ & $6 \mathrm{~d}$ & $7 c$ \\
\hline & 192 & $9 \mathrm{f}$ & $5 d$ & $2 c$ \\
\hline \multirow{2}{*}{$\csc 221^{2}$} & 54 & $16 \mathrm{e}$ & Od & $2 c$ \\
\hline & 29 & $13 \mathrm{e}$ & $6 \mathrm{c}$ & $3 c$ \\
\hline \multirow{2}{*}{$\csc 254^{2}$} & 126 & $5 f$ & $1 \mathrm{~d}$ & $6 c$ \\
\hline & 102 & $3 f$ & $\mathrm{Od}$ & $\mathrm{OC}$ \\
\hline \multirow{2}{*}{ BAT $2101^{2}$} & 59 & $4 \mathrm{f}$ & $4 \mathrm{c}$ & $4 c$ \\
\hline & 26 & $12 \mathrm{e}$ & $5 c$ & $7 c$ \\
\hline CV (\%) & & 18,34 & 55,29 & 43,30 \\
\hline
\end{tabular}

*Means followed by the same letter in the column do not differ by the Scott-Knott test $(p<0.05)$. CV: coefficient of variation; ' Virginia Group; 'Burley Group.
The fungus $A$. alternata showed the highest incidence in the seeds, ranging from 3 to $67 \%$, with the average of $26 \%$, which was confirmed by other authors. In tobacco seeds submitted to detached process, SILVA (2014) verified that A. alternata was the predominant pathogen in tobacco seeds samples produced in eight different regions in China. Due to this incidence, it is important to emphasize the seed as an inoculum source of this fungus, with the highest incidence in the samples and percentage of $13.7 \%$. In the initial growth phase of tobacco plants, MASSOLA JR. et al. (2005) reported that infection of $A$. alternata is common in hot and humid regions in Brazil, and its symptoms are characterized by brown spots on the leaves of seedlings. According to these authors, the use of healthy seeds is crucial for the disease management.

Fusarium spp. showed incidences ranging from 0 to $19 \%$, and from 0 to $18 \%$ for Cladosporium spp., with averages of 6 and $8 \%$, respectively. In China, TAN et al. (2002) detected the presence of Fusarium spp. and Cladosporium spp., whose rate of infected seeds varied between 0 and $16 \%$ for these pathogens.

Greater predominance of the fungus $A$. alternata and Fusarium spp. was observed in non-germinated seeds than in abnormal seedlings (Table 2). In non-germinated seeds, the average incidence of fungi was $10 \%$ for $A$. alternata and $5 \%$ for Fusarium spp. A positive correlation was found between the incidence of $A$. alternata and percentage of abnormal seedlings (Table 3), in addition to having caused necrotic symptoms in tobacco seedlings (Fig. 1).

According to MARCOS FILHO (2005), deterioration is a process determined by a series of changes that lead to quality reduction and, eventually, death of seeds. One of the factors that may determine this process is the presence of fungus in seeds. MENTEN (1995) cites several fungi as causes of seeds death and impairment of plants, namely Alternaria spp. and Fusarium spp.

The rate of non-germinated seeds ranged from 1 to $18.5 \%$, with the average of $6 \%$, due to physiological conditions of the seed itself, i.e., without the presence of fungi. This may also have occurred for deformed abnormal seedlings, whose rate ranged from 0.5 to $9.5 \%$. These figures explain the fact that low germination did not result only from the presence of fungi. To confirm the effect of fungi on seeds germination, one of the possibilities is to perform chemical treatment of the seeds, if this control alternative presents efficient.

For the genus Fusarium, it was observed two different spore types, which correspond to F. verticillioides (Fig. 2) and F. pallidoroseum (Fig. 3). For these species, there are no reports for damage in the tobacco culture.

The knowledge of fungi transported and their effects on the tobacco seeds and seedlings is useful, as it highlights the need for the establishment of control measures in order to avoid seeds with low health quality and ensure the production of healthy and vigorous seedlings. 
Table 2. First count (FC\%), germination (G\%), abnormal seedlings (AS\%) and fungi incidence; dead seeds (DS\%) and fungi incidence, in the germination test of tobacco seeds from the $2012 / 2013$ crop, produced by the enterprise Souza Cruz S/A.

\begin{tabular}{|c|c|c|c|c|c|c|c|c|c|c|c|}
\hline \multirow{2}{*}{ Cultivar } & \multirow{2}{*}{ Lot } & \multirow{2}{*}{ FC\% } & \multirow{2}{*}{ G\% } & \multicolumn{4}{|c|}{ AS\% } & \multicolumn{3}{|c|}{ DS\% } & \multirow[b]{2}{*}{ SWF } \\
\hline & & & & Total & Alt & Fus & DEF & Total & Alt & Fus & \\
\hline \multirow{2}{*}{$\csc 439^{1}$} & 160 & $41 \mathrm{c}$ & $52 \mathrm{e}$ & $10 a$ & $O b$ & $4 a$ & $6 a$ & $38 a$ & $32 \mathrm{a}$ & $3 d$ & $4 c$ \\
\hline & 67 & $54 \mathrm{~b}$ & $69 c$ & $6 \mathrm{~b}$ & $3 b$ & $1 \mathrm{~b}$ & $2 a$ & $25 \mathrm{~b}$ & $20 \mathrm{~b}$ & $18 a$ & $4 c$ \\
\hline \multirow{2}{*}{$\operatorname{CSC} 463^{\prime}$} & 178 & $39 c$ & $54 c$ & $12 a$ & $1 \mathrm{~b}$ & $6 a$ & $5 a$ & $41 \mathrm{a}$ & $34 a$ & $3 d$ & $5 c$ \\
\hline & 99 & $55 b$ & $65 c$ & $5 b$ & $1 \mathrm{~b}$ & $1 \mathrm{~b}$ & $4 a$ & $30 \mathrm{~b}$ & $4 \mathrm{~d}$ & $6 c$ & $18 a$ \\
\hline \multirow{2}{*}{$\operatorname{CsC} 447^{1}$} & 166 & $55 b$ & $75 b$ & $10 a$ & $\mathrm{Ob}$ & $6 a$ & $4 a$ & $15 c$ & $14 \mathrm{c}$ & $2 d$ & $3 c$ \\
\hline & 55 & $84 a$ & $90 a$ & $3 b$ & $2 b$ & $1 \mathrm{~b}$ & $1 \mathrm{a}$ & $7 d$ & $2 d$ & $4 c$ & $1 \mathrm{c}$ \\
\hline \multirow{2}{*}{$\operatorname{CSC} 416^{\prime}$} & 63 & $47 c$ & $61 d$ & $13 a$ & $1 \mathrm{~b}$ & $8 a$ & $4 a$ & $26 b$ & $22 b$ & $4 c$ & $3 c$ \\
\hline & 47 & $46 c$ & $70 c$ & $6 \mathrm{~b}$ & $4 a$ & $1 \mathrm{~b}$ & $2 a$ & $24 b$ & $14 \mathrm{c}$ & $19 a$ & $3 c$ \\
\hline \multirow{2}{*}{$\operatorname{Csc} 467^{1}$} & 127 & $57 \mathrm{~b}$ & $63 c$ & $12 a$ & $1 \mathrm{~b}$ & $9 a$ & $3 a$ & $25 \mathrm{~b}$ & $18 c$ & $4 c$ & $6 c$ \\
\hline & 124 & $56 \mathrm{~b}$ & $79 b$ & $8 b$ & $2 b$ & $2 a$ & $4 a$ & $13 c$ & $6 a$ & $9 \mathrm{~b}$ & $2 c$ \\
\hline \multirow{2}{*}{$\operatorname{CSC} 404^{1}$} & 179 & $70 \mathrm{a}$ & $72 b$ & $9 \mathrm{~b}$ & $O b$ & $2 a$ & $4 \mathrm{a}$ & $19 c$ & $10 \mathrm{c}$ & $1 \mathrm{~d}$ & $8 b$ \\
\hline & 100 & $63,5 b$ & $79 b$ & $4 b$ & $1 \mathrm{~b}$ & $2 a$ & $1 \mathrm{a}$ & $17 \mathrm{c}$ & $12 \mathrm{c}$ & $6 c$ & $2 c$ \\
\hline \multirow{2}{*}{$\operatorname{CsC} 454^{1}$} & 177 & $56,5 b$ & $76 \mathrm{~b}$ & $6 b$ & $\mathrm{Ob}$ & $2 a$ & $4 a$ & $18 c$ & $13 c$ & $2 d$ & $14 a$ \\
\hline & 103 & $61,5 b$ & $79 b$ & $7 b$ & $1 \mathrm{~b}$ & $3 a$ & $2 a$ & $14 \mathrm{c}$ & $10 \mathrm{c}$ & $4 c$ & $4 c$ \\
\hline \multirow{2}{*}{$\operatorname{CsC} 4704^{\prime}$} & 107 & $53 b$ & $73 \mathrm{~b}$ & $13 a$ & $2 b$ & $3 a$ & $8 a$ & $14 c$ & $9 c$ & $7 c$ & $4 c$ \\
\hline & 28 & $65,5 a$ & $83 \mathrm{~b}$ & $8 b$ & $3 b$ & $1 \mathrm{~b}$ & $4 a$ & $9 \mathrm{~d}$ & $2 \mathrm{~d}$ & $3 d$ & $6 c$ \\
\hline \multirow{2}{*}{$\operatorname{CsC} 497^{1}$} & 92 & $40,5 c$ & $67 c$ & $8 b$ & $O b$ & $5 a$ & $3 a$ & $25 b$ & $14 \mathrm{c}$ & $2 d$ & $10 \mathrm{~b}$ \\
\hline & 89 & $34,5 \mathrm{c}$ & $55 c$ & $13 a$ & $1 \mathrm{~b}$ & $4 a$ & $8 a$ & $32 \mathrm{a}$ & $12 c$ & $1 \mathrm{~d}$ & $18 a$ \\
\hline \multirow{2}{*}{$\operatorname{CsC} 444^{1}$} & 115 & $71 a$ & $82 \mathrm{a}$ & $4 b$ & $1 \mathrm{~b}$ & $1 \mathrm{~b}$ & $2 a$ & $14 c$ & $2 d$ & $6 c$ & $6 c$ \\
\hline & 50 & $72 a$ & $81 a$ & $6 \mathrm{~b}$ & $1 \mathrm{~b}$ & $2 a$ & $3 a$ & $14 c$ & $9 c$ & $6 c$ & $3 c$ \\
\hline \multirow{2}{*}{$\csc 401^{1}$} & 45 & $54,5 b$ & $70 c$ & $9 a$ & $3 b$ & $2 a$ & $4 a$ & $21 \mathrm{~b}$ & $10 c$ & $12 \mathrm{~b}$ & $2 c$ \\
\hline & 44 & $67 a$ & $74 b$ & $8 b$ & $4 a$ & $2 a$ & $2 a$ & $18 \mathrm{c}$ & $8 d$ & $13 b$ & $2 c$ \\
\hline \multirow{2}{*}{$\operatorname{CsC} 4703^{1}$} & 34 & $29 c$ & $71 \mathrm{c}$ & $12 \mathrm{a}$ & $4 a$ & $4 a$ & $4 a$ & $17 \mathrm{c}$ & $10 c$ & $10 \mathrm{~b}$ & $3 c$ \\
\hline & 97 & $28 c$ & $77 \mathrm{~b}$ & $12 \mathrm{a}$ & $5 a$ & $4 a$ & $4 a$ & $11 \mathrm{c}$ & $6 \mathrm{~d}$ & $4 c$ & $2 c$ \\
\hline $\csc 405^{1}$ & 120 & $52 c$ & $75 b$ & $14 \mathrm{a}$ & $4 a$ & $6 a$ & $4 a$ & $11 \mathrm{c}$ & $6 \mathrm{~d}$ & $4 c$ & $4 c$ \\
\hline \multirow{2}{*}{ BAT $2301^{2}$} & 163 & $49 c$ & $61 c$ & $8 b$ & $\mathrm{Ob}$ & $2 a$ & $6 a$ & $31 a$ & $14 \mathrm{c}$ & $1 \mathrm{~d}$ & $17 a$ \\
\hline & 26 & $57 \mathrm{~b}$ & $78 b$ & $10 a$ & $4 a$ & $2 a$ & $4 \mathrm{a}$ & $12 \mathrm{c}$ & $4 \mathrm{~d}$ & $6 c$ & $2 c$ \\
\hline \multirow{2}{*}{$\csc 2305^{2}$} & 167 & $57 \mathrm{~b}$ & $59 d$ & $13 a$ & $6 a$ & $1 \mathrm{~b}$ & $6 a$ & $28 a$ & $13 c$ & $1 \mathrm{~d}$ & $14 a$ \\
\hline & 192 & $50 c$ & $74 b$ & $12 \mathrm{a}$ & $3 b$ & $O b$ & $9 a$ & $14 c$ & $4 d$ & $\mathrm{Od}$ & $10 \mathrm{~b}$ \\
\hline \multirow{2}{*}{$\csc 221^{2}$} & 54 & $33 c$ & $84 a$ & $6 \mathrm{~b}$ & $2 b$ & $2 a$ & $2 a$ & $10 c$ & $3 d$ & $4 c$ & $3 c$ \\
\hline & 29 & $44 c$ & $69 c$ & $12 \mathrm{a}$ & $2 b$ & $2 a$ & $8 a$ & $19 c$ & $3 d$ & $7 c$ & $9 \mathrm{~b}$ \\
\hline \multirow{2}{*}{$\operatorname{CSC} 254^{2}$} & 126 & $71 \mathrm{a}$ & $87 a$ & $7 b$ & $1 \mathrm{~b}$ & $O b$ & $6 a$ & $6 \mathrm{~d}$ & $1 \mathrm{~d}$ & $1 \mathrm{~d}$ & $6 c$ \\
\hline & 102 & $75 a$ & $84 a$ & $4 b$ & $O b$ & $O b$ & $4 a$ & $12 c$ & $1 \mathrm{~d}$ & Od & $10 \mathrm{~b}$ \\
\hline BAT $2101^{2}$ & 59 & $53 \mathrm{~b}$ & $71 c$ & $16 a$ & $6 a$ & $2 a$ & $10 a$ & $13 c$ & $6 d$ & $4 d$ & $6 c$ \\
\hline Mean & & $53,3 b$ & $71,3 a$ & $4,6 \mathrm{~b}$ & $1,8 b$ & $2,9 a$ & $4,2 \mathrm{a}$ & $19,6 \mathrm{c}$ & $10,3 \mathrm{c}$ & $5,3 c$ & $6 c$ \\
\hline CV (\%) & & 23,92 & 9,72 & 52,38 & 67,40 & 89,34 & 75,17 & 30,29 & 45,69 & 44,80 & 43,80 \\
\hline
\end{tabular}

*Means followed by the same letter in the column do not differ by the Scott-Knott test ( $p<0.05)$; CV: coefficient of variation; Alt: Alternaria alternata; Fus: Fusarium spp.; DEF: deformed seedlings; SWF: seeds without fungi; 'Virginia Group; 'Burley Group.

Table 3. Coefficients of linear correlation ( $r$ ) between the incidences of fungi observed and physiological quality of 34 samples of tobacco seeds.

\begin{tabular}{lcccc}
\hline Incidence on seeds & FC & Germination & Abnormal seedlings & Dead seeds \\
\hline Alternaria alternata & -0.2554 & $-0.5001^{* *}$ & 0.1165 & $0.5655^{* *}$ \\
\hline Fusarium spp. & 0.0059 & 0.1731 & -0.3220 & -0.0932 \\
\hline
\end{tabular}

FC: First count of germination; **significant at $1 \%$ probability by the $t$ test. 

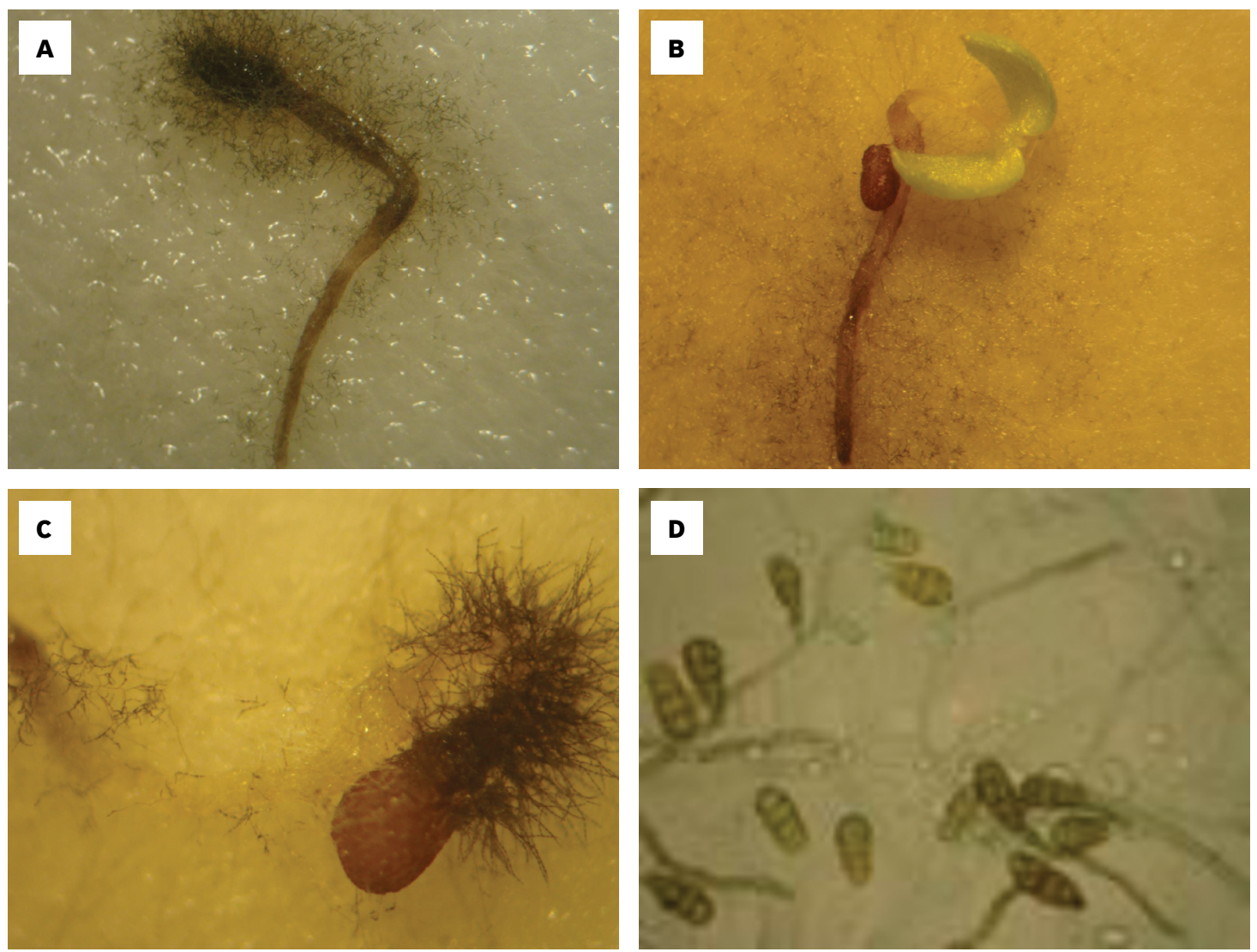

Figure 1. (A, B, C) Growth of Alternaria alternata in tobacco seedlings showing necrotic symptoms in the hypocotyl; (D) conidia of A. alternata.
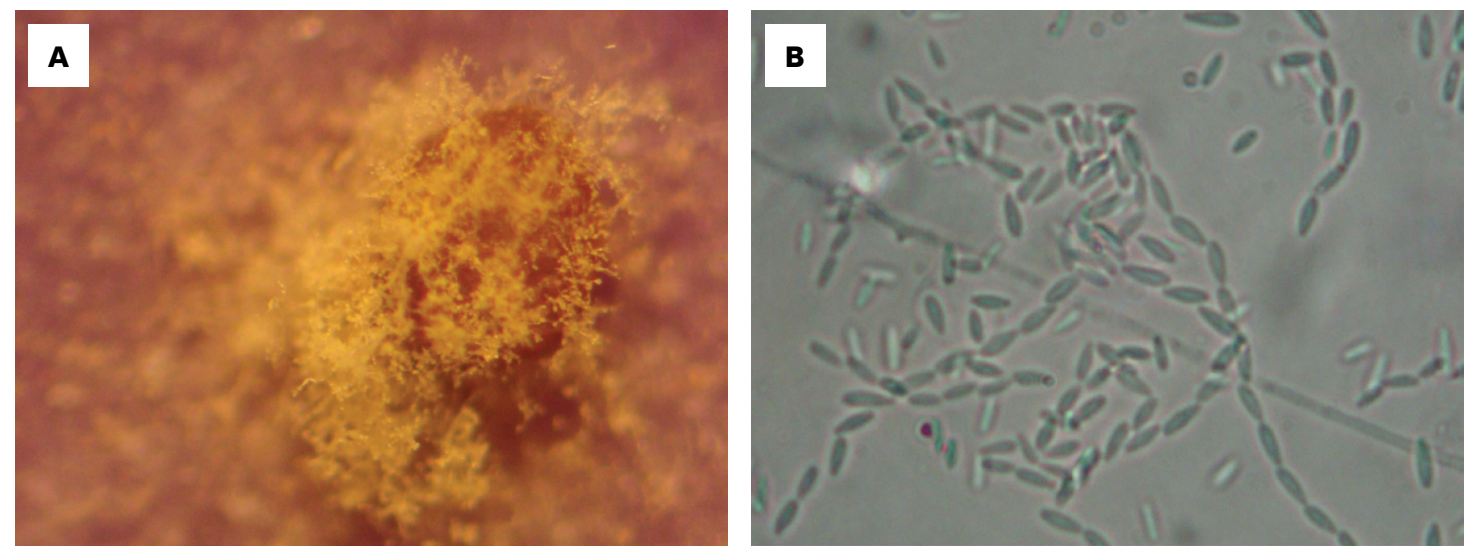

Figure 2. (A) Growth of Fusarium verticillioides in tobacco seed; (B) conidia of $F$. verticillioides.
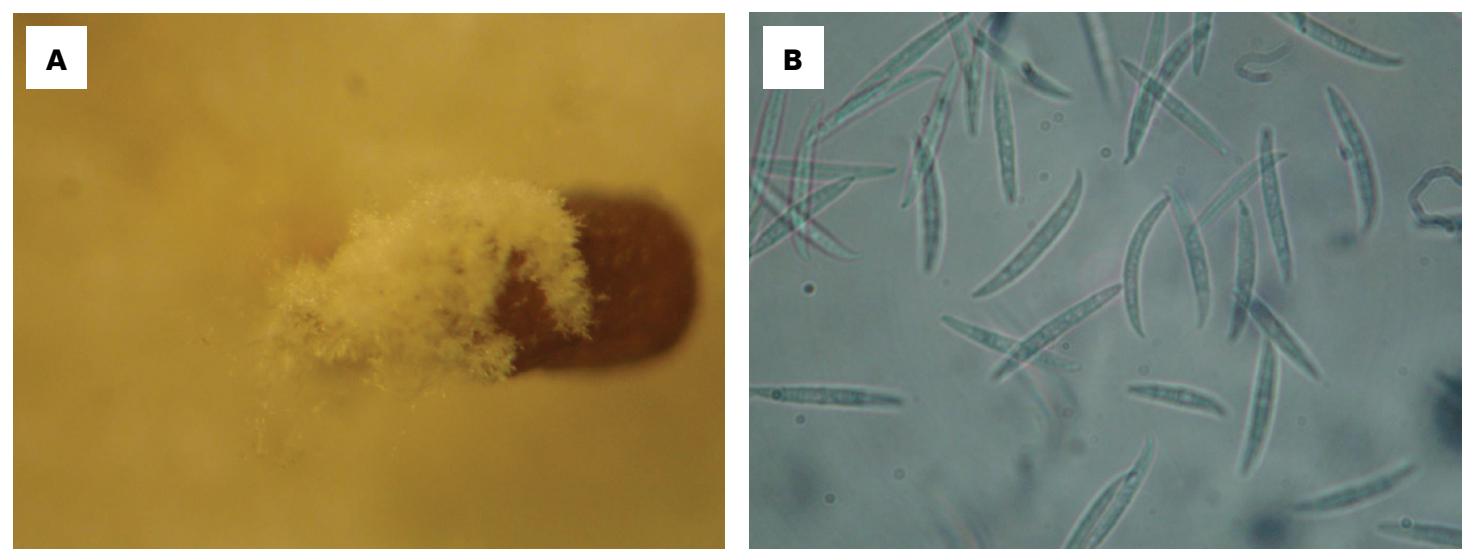

Figure 3. (A) Growth of Fusarium pallidoroseum in tobacco seed; (B) conidia of $F$. pallidoroseum. 
In the present project, we showed that tobacco seeds can carry several fungi including A. alternata, F. verticillioides and F. pallidoroseum. Furthermore, the fungus $A$. alternata might affect tobacco seed germination, as it causes seed death.

\section{ACKNOWLEDGMENTS}

To the enterprise Souza Cruz, for providing the seed samples used in the current study.

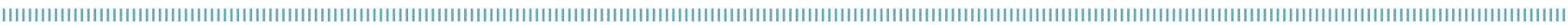

\section{REFERENCES}

BARNETT, H.L.; HUNTER, B.B. Illustrated Genera of Imperfect Fungi, $4^{\text {th }}$ Edition. The American Phytopathological Society, St. Paul, MN, USA 1998, 218p.

BRASIL. Ministério da Agricultura, Pecuária e Abastecimento. Regras para análise de sementes. Secretaria de Defesa Agropecuária. - Brasília, Mapa/ACS, 2009a., 399 p.

BRASIL. Ministério da Agricultura, Pecuária e Abastecimento. Manual de Análise Sanitária de Sementes. Brasília, DF: Mapa/ ACS, 2009b, 200p.

FERRAZ, I.D.K.; CALVI, D.P. Teste de Germinação. In: Lima Junior, M.J.V. (Ed.). Manual de Procedimentos para Análise de Sementes Florestais. Manaus: UFAM, v.1, p.55-110, 2010.

KIMATI, H. Doenças do feijoeiro. In: GALLI, F. (Coord.). Manual de fitopatologia: doenças das plantas cultivadas. São Paulo: Agronômica Ceres, cap.19, p.297-318, 1980.

MACHADO, J.C. Patologia de sementes fundamentos e aplicações. Brasília: MEC/ESAL/FAEPE, 1988, $106 \mathrm{p}$.

MARCOS FILHO, J. Fisiologia de sementes de plantas cultivadas. Piracicaba: FEALQ, Piracicaba, SP, 2005, 495 p.

MASSOLA JR., N.S.; PULCINELLI, C.E.; JESUS JR., W.C.; GODOY, C.V. Doenças do fumo (Nicotianatabacum). In: KIMATI, H.; AMORIM, L.; REZENDE, J.A.M.; BERGAMIN FILHO, A.; CAMARGO, L.E.A. (Eds.). Manual de Fitopatologia. Vol. 2. Doenças das
Plantas Cultivadas. 4a Edição. São Paulo, Agronômica Ceres, 2005, p.361-371.

MENTEN, J.O.M. ed. Patógenos em sementes: detecção, danos e controle químico. São Paulo: Ciba Agro, 1995, p.115-136.

NEERGAARD, P. Seed pathology. London, UK, 1979, 838p.

RICHARDSON, M.J. An Annotated List of Seed-Borne Diseases.Fourth Edition.International Seed Testing Association, Zurich, 1990, 387 p.

SEGATO, S.V.; GABALDI, F.C. Fungos associados às sementes de fumo (Nicotianatabacum L.). Nucleus, Ituverava, SP, v.9, n.2, p.229-234, 2012.

SILVA, F.A.S.; AZEVEDO, C.A.V. Versão do programa computacional Assistat para o sistema operacional Windows. Revista Brasileira de Produtos Agroindustriais, Campina Grande, v.4, n. 1, p.71-78, 2002.

SILVA, H.P. Colheita, secagem e extração de sementes de tabaco. 2014. 106f. Tese (Doutorado em Agronomia) - Universidade Federal de Lavras, Lavras, 2014.

SINDITABACO. Evolução das exportações - Região Sul do Brasil. 2015. Available from: http://sinditabaco.com.br/sobre-o-setor/ exportacoes/. Accessed on: Aug 152015.

TAN, Z.X., FANG, D.H., BAI, Y.F., ZHANG, H., LU, J.P. Testing of seed-borne fungi in tobacco seeds from Yunnan Province. Journal of Southwest Agricultural University, Tokyo, v.24, p.428-430, 2002. 